\title{
Coal fire mapping of East Basuria Colliery, Jharia coalfield using vertical derivative technique of magnetic data
}

\author{
S K PaL*, Jitendra Vaish, Sahadev Kumar and Abhay Kumar Bharti \\ Department of Applied Geophysics, Indian School of Mines, Dhanbad 826 004, India. \\ ${ }^{*}$ Corresponding author.e-mail: sanjitism@gmail.com
}

The present study deals with the coal fire mapping of East Basuria Colliery, Jharia coalfield, India, using the magnetic method. It is based on the fact that rise in temperature would result significant changes in magnetic susceptibility and thermo-remanent magnetization (TRM) of the overlying rocks. Magnetism increases slowly with the rise of temperature until the Curie temperature. Generally, rock/ overburden loses magnetization and becomes paramagnetic due to heating to Curie temperature, which results with significant reduction in magnetic susceptibility. However, magnetism increases significantly after cooling below the Curie temperature. Several data processing methods such as diurnal correction, reduction to pole (RTP), first and second vertical derivatives have been used for analysis of magnetic data and their interpretation. It is observed that the total magnetic field intensity anomaly of the area varies approximately from 44850 to $47460 \mathrm{nT}$ and the residual magnetic anomaly varies approximately from -1323 to $1253 \mathrm{nT}$. The range of the magnetic anomaly after RTP is approximately 1050-1450 nT. About 20 low magnetic anomaly zones have been identified associated with active coal fire regions and 11 high magnetic anomaly zones have been identified associated with non-coal fire regions using vertical derivative techniques.

\section{Introduction}

Coal seam fire, coal mine fire as well as fire in coal waste or storage piles are a general phenomenon worldwide and pose a great threat to national economy, environment, ecology and health of people living in its proximity. The mapping and understanding of hidden subsurface coal fire is a challenging task. Coal fire is a serious problem in major coal producing countries, including, China, India, USA and South Africa (Rosema et al. 1999; Bell et al. 2001; Stracher 2004; Stracher and Taylor 2004; Zhang et al. 2004; Gangopadhyay 2006; Kuenzer et al. 2008; Mishra et al. 2011; Bharti et al. 2014, 2016; Singh et al. 2015; Srivardhan et al. 2016), Australia, Russia, Poland and Indonesia (Wachiwicz 2008; Ide et al. 2011; Ide and Orr 2011).

Remote sensing technique is being used for coal mine fire study with airborne thermal scanner since early 1960's. Satellite remote sensing using thermal infrared images are frequently utilized to detect coal fire regions based on surface temperature anomalies at coal fire areas, mostly in China, India and USA (Mansor et al. 1994; Prakash et al. 1995, 1997; Prakash and Gupta 1998, 1999; Gangopadhyay 2003; Voigt et al. 2004; Kuenzer et al. 2007a, 2007b, 2008; Kuenzer and Stracher 2011; Mishra et al. 2011). Satellitebased thermal images are not sufficient for detection of deeper thermal anomalies (Zhang 1998). The true extent of the subsurface combustion region may not be determined solely from this remote sensing technique. Interferometric Synthetic Aperture Radar (InSAR) can detect subtle surface deformation over time (Massonnet and Feigle 1998). However, the subsidence may or may not always correspond to an active fire region and the expected pixel resolution is about 20-100 m (Burgmann et al. 2000).

Keywords. Coal fire mapping; proton precession magnetometer; reduction to magnetic pole; vertical derivatives. 
Several researchers around the world have used magnetic method to characterize underground coal fires (Zhang 1980; Hooper 1987; Schueck 1990; Bandelow and Gielisch 2004; Sternberg and Lippincott 2004; Wei et al. 2005; Gielisch 2007; Schaumann et al. 2008; Sternberg et al. 2008; Chen and Shao 2010; Ide et al. 2011; Vaish and Pal 2013, 2015a, 2016; Kumar et al. 2015). Magnetic survey provides high resolution coal fire mapping, which delineates previously burned, active coalfire and non-coalfire regions. Generally, mapping and understanding of subsurface coal fires are carried on the basis of magnetic properties of materials, and those changes with the temperatures rise, either above or below, the Curie temperature. The combustion of subsurface coal releases much heat, making the temperature of overlying rock higher than the Curie temperature. This high temperature causes significant changes in magnetic properties (magnetic susceptibility and thermo-remanent magnetization (TRM)) and thereby results in an observable magnetic anomaly at the surface in an active coal fire area (Shao et al. 2014). The characteristics of magnetic behaviour with temperature (Xiong and Yu 2013; Song and Kuenzer 2014) are classified into four main stages:

- Magnetism is very small if temperature is lower than $400^{\circ} \mathrm{C}$;

- Magnetism increases slowly with temperature rise until the Curie temperature;

- Magnetism disappears, if temperature is higher than the Curie temperature; and

- Magnetism greatly increases after cooling below the Curie temperature.

Different minerals are formed due to coal fire activity and their magnetic strengths depend on the temperature and the amount of oxygen available during thermal alteration process (Hooper 1987; Gielisch 2007; Ide et al. 2011).

Different aspects of coal fires in Jharia coalfield and its surroundings have been extensively studied by various researchers (Bhattacharya et al. 1991; Saraf et al. 1995; Prakash and Gupta 1998, 1999; Michalski 2004; Tripathi 2005; Agarwal et al. 2006; Chatterjee 2006; Kuenzer et al. 2007a, 2008; Singh et al. 2007) using satellite remote sensing methods only. So far, only a few surface geophysical methods have been applied for coal fire research in India. In the present study, magnetic method of geophysical investigation has been used for coal fire mapping of East Basuria Colliery, Jharia coalfield, India. Initially, a brief history of coal fires of the Jharia coalfield followed by East Basuria Colliery have been discussed. Subsequently, details of magnetic data acquisition and processing have been conversed. Further, detail observations on the obtained results are discussed to characterize the subsurface coal fires.

\section{Study area}

The Jharia coalfield is a major coal producing basin in India, consisting 23 large underground and 9 large open cast mines, which is severely affected by coal fire. The Jharia coalfield is located in Dhanbad district, Jharkhand, India which is one of the most important Gondwana coalfields of Damodar valley in India. Owing to the presence of high quality coking coal in Jharia coalfield, it is significant to study the subsurface coal fire activity, which started since 1916, due to excessive and unplanned coal exploration. Jharia coalfield was nationalized in 1970 and over the past four decades, the coal fires spread in many areas. Different researchers have reported that coal fires are still active at about 70 collieries in Jharia coalfield (Michalski 2004). Most of the coal fires in Jharia coalfield were ignited by spontaneous combustion of coal, subsequent to opencast and underground mining. Unplanned coal exploitation without fire-prevention arrangements prior to nationalization might have been a possible reason for these fires (Bharat Coking Coal 2003; CMPDI 2003; Coal International 2003; World Bank Group 2003; Agarwal et al. 2006).

The rock formations of Jharia coalfield unconformably overlay the Archean basement and belong mainly to the Lower Gondwana group of Permian age comprising Talchir, Barakar, Barren measures and Raniganj formations, from bottom to top. The present study area lies within the geographical coordinates between $23^{\circ} 47^{\prime} 34^{\prime \prime}-23^{\circ} 47^{\prime} 53^{\prime \prime} \mathrm{N}$ latitudes and $86^{\circ} 21^{\prime} 59^{\prime \prime}-86^{\circ} 22^{\prime} 16^{\prime \prime} \mathrm{E}$ longitudes. All the working coal seams lie in the Barakar Formation of Lower Gondwana group of Early Permian age. Barakar Formation comprises predominantly sandstone of variable grain size, intercalation of sandstone and shale, grey and carbonaceous shale and coal seams. The general strike of the formation is $\mathrm{E}-\mathrm{W}$ and dip of the coal seam varies from $10^{\circ}$ to $15^{\circ}$ towards south (Singh et al. 2004). The natural topography has been severely affected due to mining activities, dumping of overburden material and land subsidence. Some parts of active coal fire zone have been covered by dumping of overburden material to prevent and combat against further exaggeration of coal fire in the surroundings.

The record of first fire in East Basuria colliery was noticed in V/VI seam quarry in 1976. Afterwards, in 1993, during the construction of nearby railway sidings, the top soil cover of East Basuria region was excavated. This helped (to the breathing of air) the V/VI seam-fire of East Basuria Colliery. Then, the quarry was filled with overburden 
and the surface area was sealed with soil. Later on, blazing fire was reported in three different galleries of V/VI coal seam. Again in 1995, a blazing fire was noticed on the eastern edge of the quarry. To prevent further advance of fire towards the adjoining area, the siding area was refilled by overburden material. Water pools were made over the filled up area in 1996 but by that time, the fires spread to the VIII and VIIIA seams, which resulted in uncontrolled subsidence and potholing, etc. In
1997-1998, an attempt was made to control the eastward advance of the fire by cutting a trench, keeping V/VI seam as base. However, this attempt also proved futile as the fire crossed into the trench, while trench cutting was in progress (Bharat Coking Coal 2003; CMPDI 2003; Coal International 2003; World Bank Group 2003). Location map of the study area (East Basuria Colliery) along with generalized geological map of Jharia coalfield is shown in figure 1.

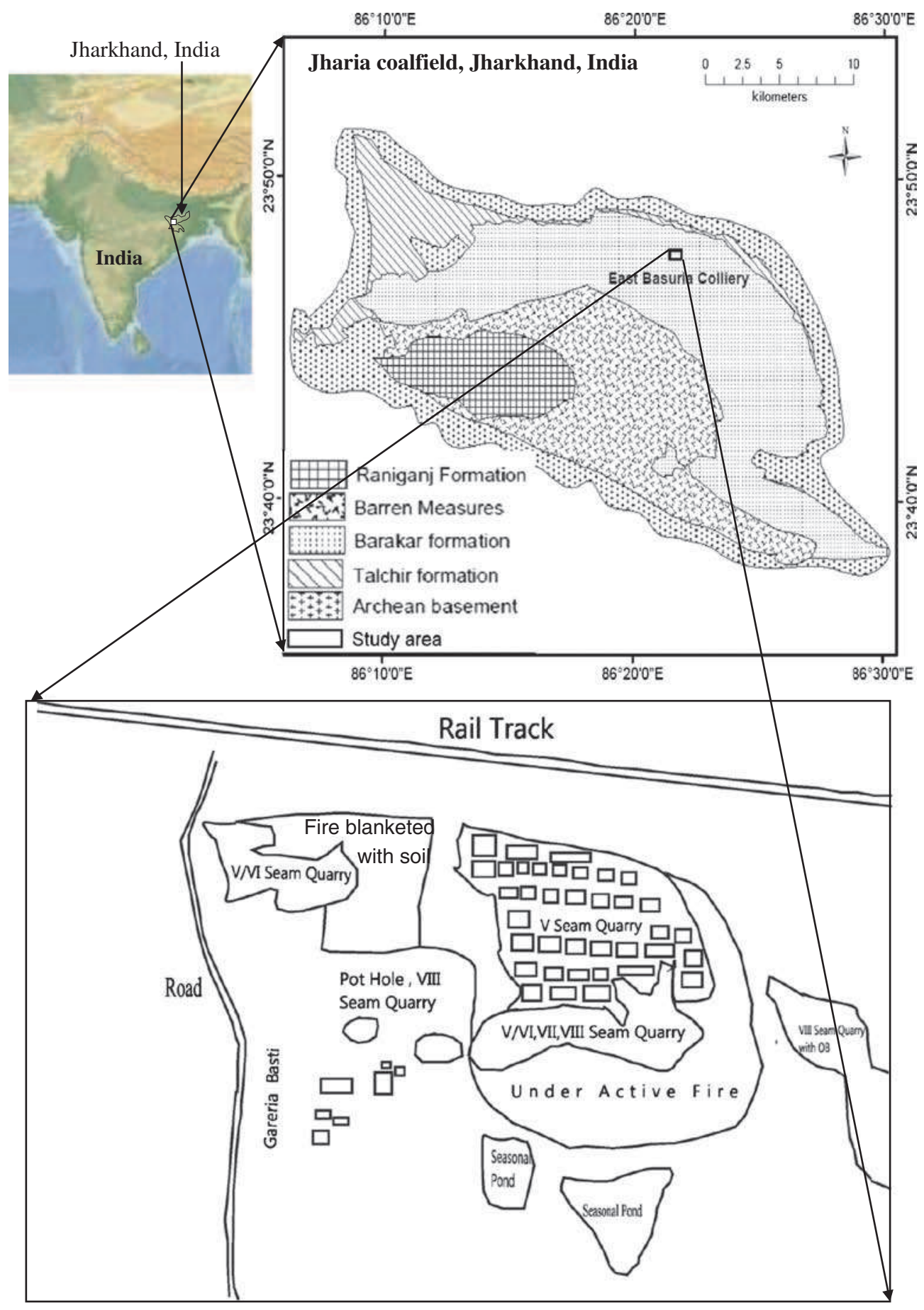

Figure 1. Location map of the study area (East Basuria Colliery) along with generalized geological map of Jharia coalfield. 


\section{Methodology}

GSM-19T proton precession magnetometer with an in-built GPS (resolution $0.6 \mathrm{~m}$ ) has been used for magnetic data acquisition. Total magnetic field intensity has been measured with resolution of 0.01 $\mathrm{nT}$, sensitivity of $0.15 \mathrm{nT} / \mathrm{Hz}$ and absolute accuracy of $0.2 \mathrm{nT}$. Total 2865 magnetic data points have been taken along 42 magnetic profiles over different parts of East Basuria Colliery, in different directions with $10 \mathrm{~m}$ profile spacing and $5 \mathrm{~m}$ data station spacing along the profile direction. At the start of each traverse, a base station has been established over a non-coal fire area at which base station readings have been obtained at 30-min interval for the correction of diurnal variations of total magnetic field.

GSM-19T proton precession magnetometer has a signal quality indicator, which is presented in the form of XY, where $\mathrm{X}$ and $\mathrm{Y}$ are between ' 0 ' and '9' (Breiner 1999; GSM-19T v7.0 instruction manual, 2008 GEM Systems, Canada). X is associated with measurement time. This is one sort of gradient indicator, where ' 9 ' means measurement time is maximum and ' 0 ' means measurement time is too short. Y represents the area under signal amplitude coincident with the time of measurement, where ' 9 ' means optimal conditions and ' 0 ' means unacceptable reading. The value of $\mathrm{X}=0$ causes $\mathrm{Y}=0$, but not vice versa. Different spikes and dropped signals are characterized by low quality signal with 00 to $88(\mathrm{X}=0-8$ and $\mathrm{Y}=0-8)$. In the physical domain, spikes and dropped signals (0088 , i.e., $\mathrm{X}=0-8$ and $\mathrm{Y}=0-8$ ) have been removed. Only the good readings with signal 99 ( $\mathrm{X}=9$ and $\mathrm{Y}=9$ ) have been selected for further processing. Generally, data spikes are encountered close to large metallic objects at the surface.

Diurnal correction is applied to rectify the temporal variation of the geomagnetic field, which is primarily caused by electro-magnetic radiation from the Sun (Khalil 2012). The acquired magnetic readings have been corrected for diurnal variation of Earth's ambient magnetic field based on the drift observed in the repeated base station readings. Generally, the Earth's magnetic field except for the magnetic poles is inclined from the vertical (Baranov 1957; Baranov and Naudy 1964; Mendonca and Silva 1993). The most obvious approach to this problem is to reduce the data to the magnetic pole (RTP), assuming that all the observed magnetic fields are due to induced magnetic effects. This pole reduction has been calculated in the frequency domain (Grant and Dodds 1972).

Vertical and horizontal derivative of potentialfield anomalies have been used by various researchers (Rao et al. 1981; Reid et al. 1990; Marcotte et al. 1992; Boschetti 2005; Fedi and Florio 2001, 2013;
Gonenc 2014; Pal and Majumdar 2015; Vaish and Pal 2015b), for enhancement of anomaly and delineation of shallow structures. Derivative filters have been established as powerful techniques for enhancing the higher wave number components of an anomaly field which also reduce anomaly complexity, allowing a clear imaging of the causative structures (Ravat 1996; Khalil 2012). However, the transformation can be noisy since it may amplify short wavelength noise. Vertical derivatives have been mathematically derived from the magnetic RTP data (Hood et al. 1979; Khalil 2012). The first vertical derivative has been obtained through the computation of second horizontal derivatives and their integration, through the application of Laplace equation (Agarwal and Lal 1969; Gupta and Ramani 1982; Fedi and Florio 2002). The second vertical derivative has been obtained from the horizontal derivatives because the potential field satisfies Laplace's equation (Agarwal and Lal 1969; Gupta and Ramani 1982; Blakely 1996).

\section{Results and discussions}

The diurnal correction has been applied on the recorded magnetic readings based on the drift measured in the base station readings. The diurnal fluctuation observed during data acquisition at the site is about $50 \mathrm{nT}$. Total magnetic field intensity map has been generated using only the readings with signal of 99. Total magnetic field intensity map and residual magnetic anomaly map of East Basuria Colliery are shown in figure 2(a) and (b), respectively. It is observed that total magnetic field intensity anomaly varies from 44850 to $47460 \mathrm{nT}$. The coordinate of center point of the study area is $86^{\circ} 21^{\prime} 51.8^{\prime \prime} \mathrm{E}$ longitude and $23^{\circ} 47^{\prime} 45.56^{\prime \prime} \mathrm{N}$ latitude. According to the International Geomagnetic Reference Field (IGRF), the geomagnetic declination, inclination and total magnetic field of the study area were: $0.34^{\circ}, 35.91^{\circ}$ and $46,173.9 \mathrm{nT}$, respectively during the period of the survey in October 2012. The total magnetic field observed over natural topography was about $46,160 \pm 10 \mathrm{nT}$. The residual map has been constructed by subtracting the Earth's main field from the diurnal corrected magnetic data of the area. It has been observed that the residual magnetic anomaly varies from about -1323 to $1253 \mathrm{nT}$. Further, the residual magnetic data have been corrected by 'reduced to north magnetic pole' (RTP) for the removal of lateral shifts and asymmetries caused by the local orientation of the magnetic anomaly. Magnetic anomaly map after pole reduction of residual magnetic field intensity is shown in figure 3(a). It has been observed that the magnetic anomaly after RTP varies from about -1050 to $1450 \mathrm{nT}$. 

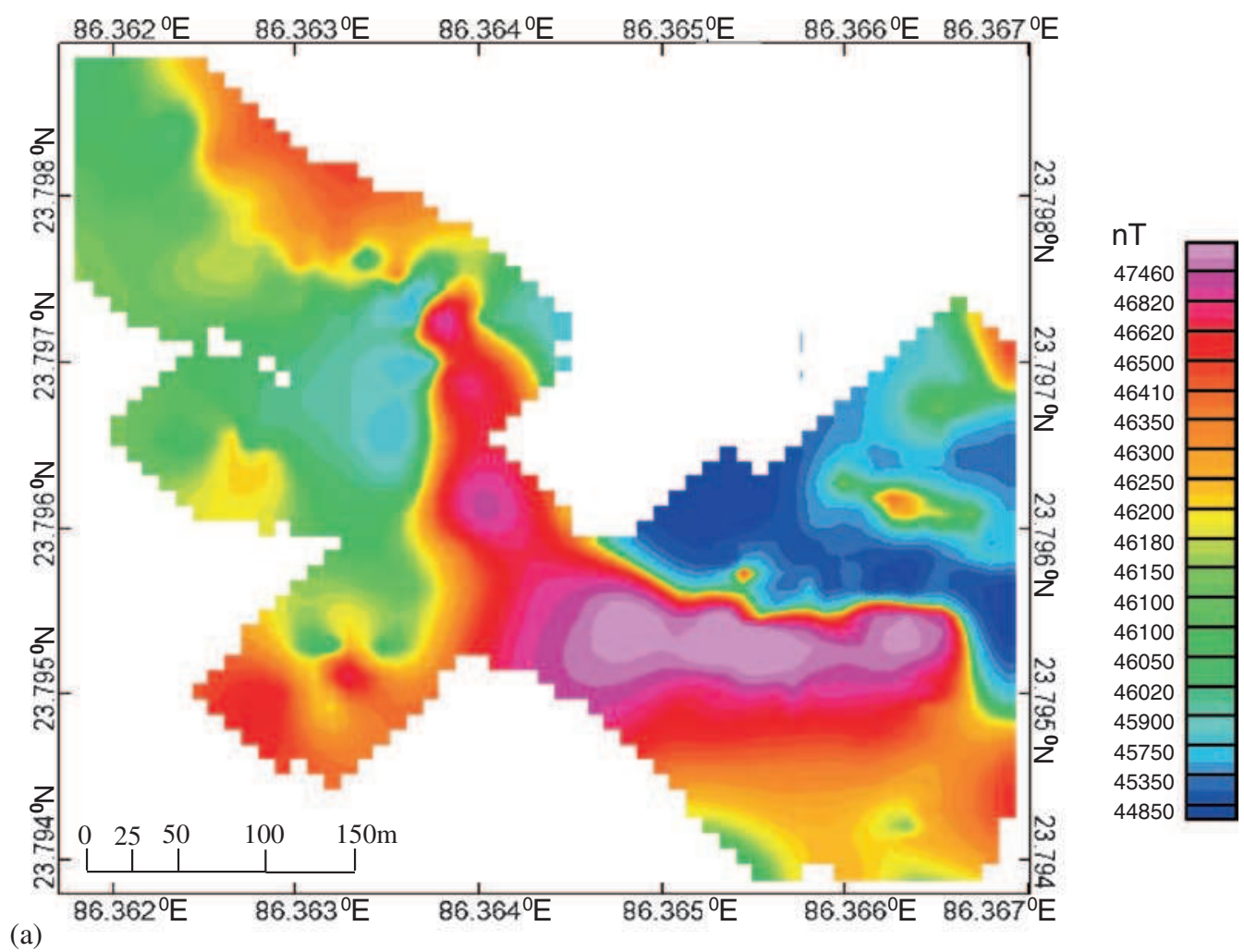

(a)
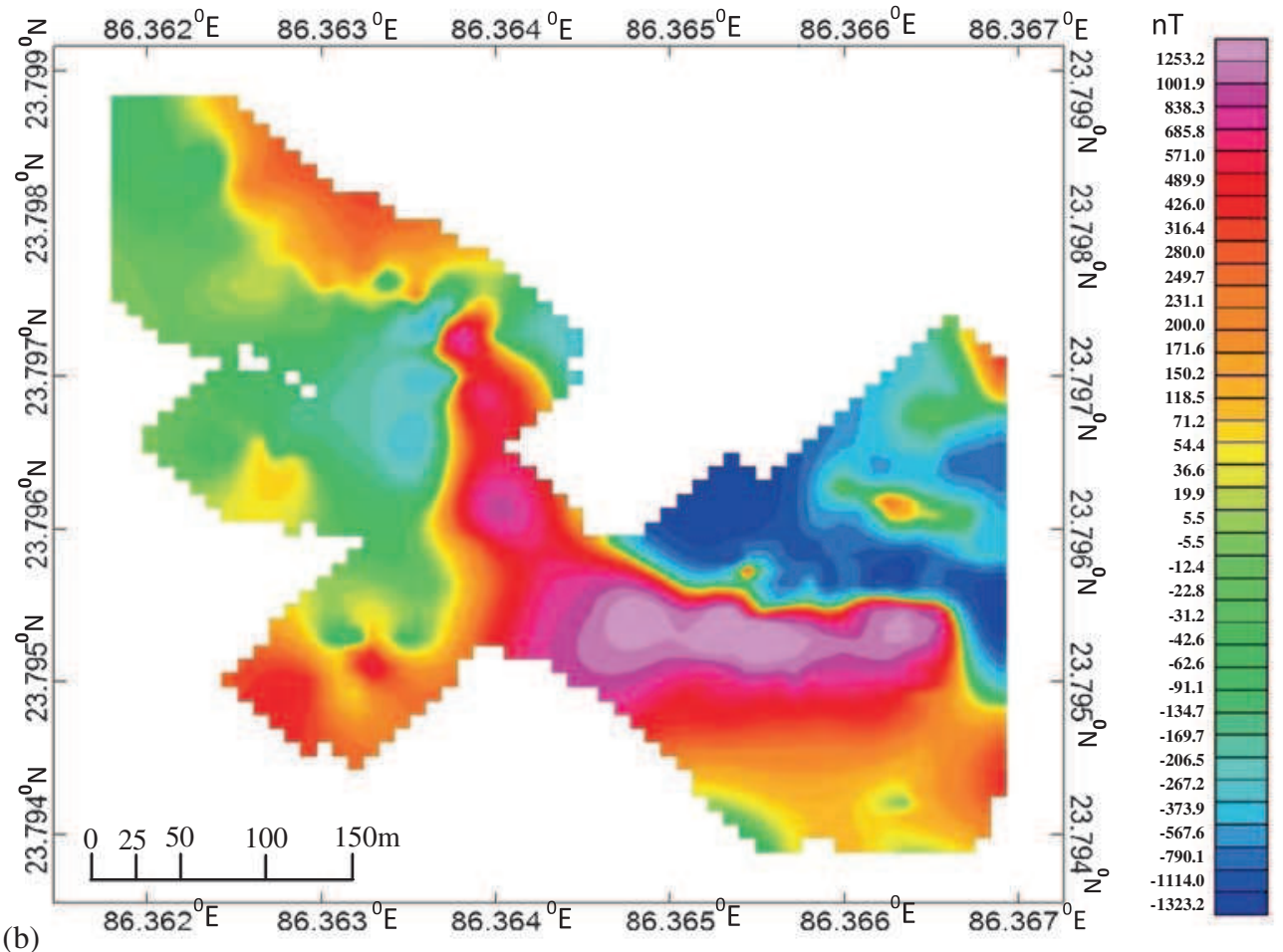

Figure 2. (a) Total magnetic field intensity map and (b) residual magnetic anomaly map of East Basuria Colliery.

Comparing figures 2(b) and 3(a), it is clear that the overall values of magnetic anomalies after RTP, have been increased approximately by $200-250 \mathrm{nT}$ and magnetic anomalies are enhanced.

RTP map (figure 3a) reveals that the study area is characterized by two different patterns of prominent magnetic field variations. Nine magnetic high anomaly (H1-H9) zones with approximate value of 20-1450 nT and 12 low magnetic anomaly (L1-L12) zones with approximate value of -150 to $-1050 \mathrm{nT}$ have been delineated in the RTP map (figure 3a). The low magnetic anomaly zone, L1 is characterized by highly active coal fire/smokes/blaze of about $510^{\circ} \mathrm{C}$ partially exposed on the surface 


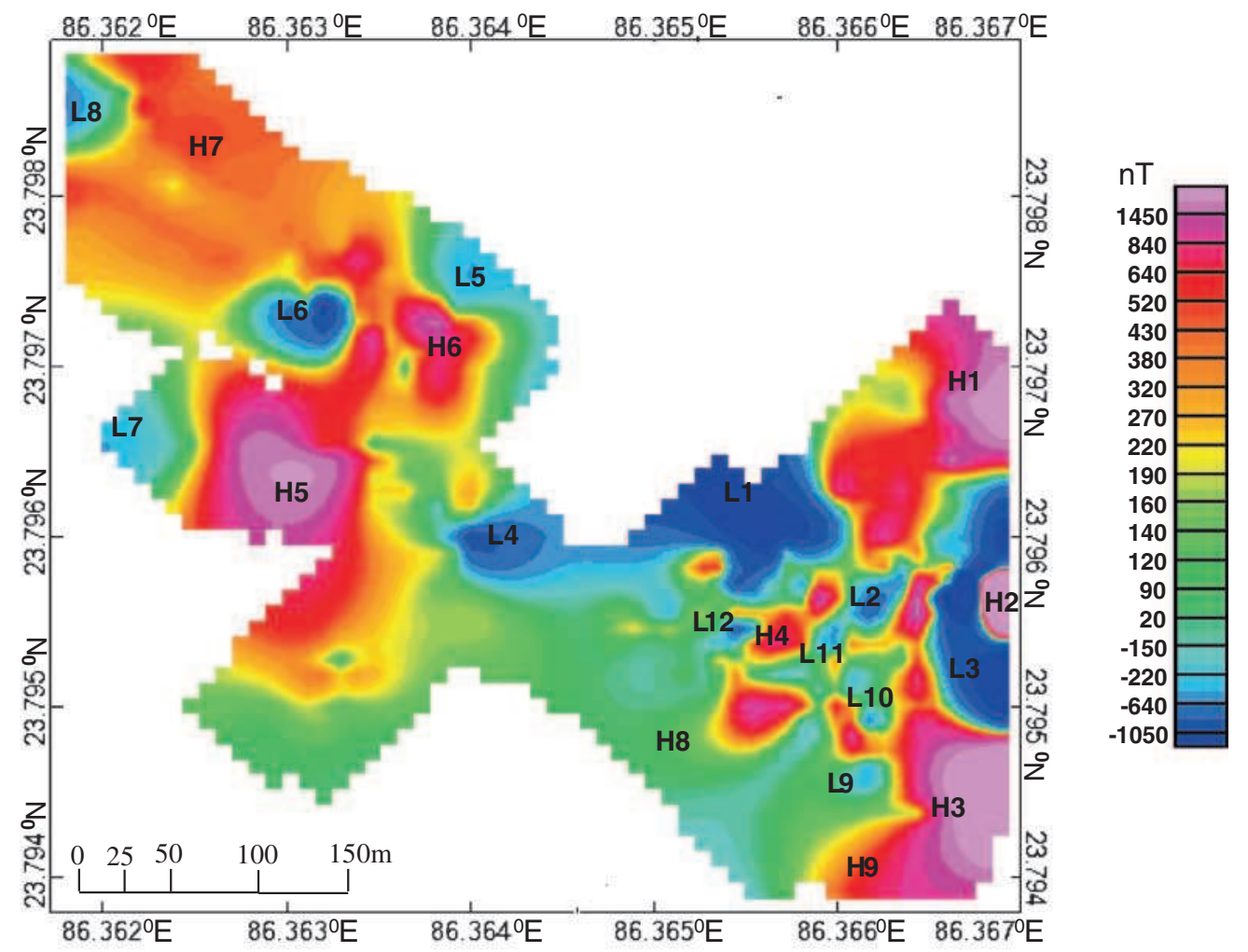

(a)
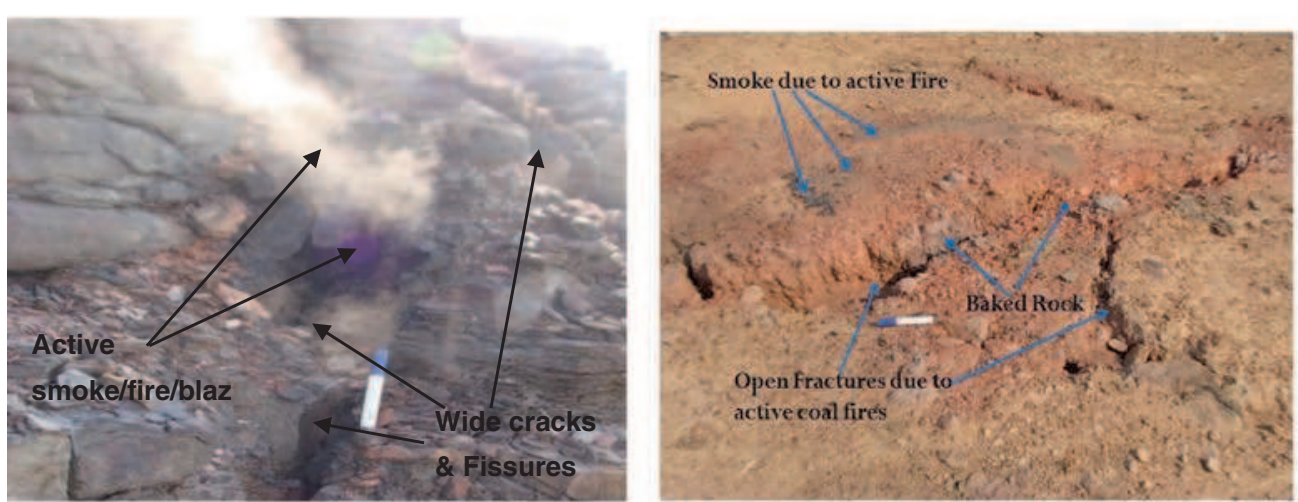

(b)

(c)
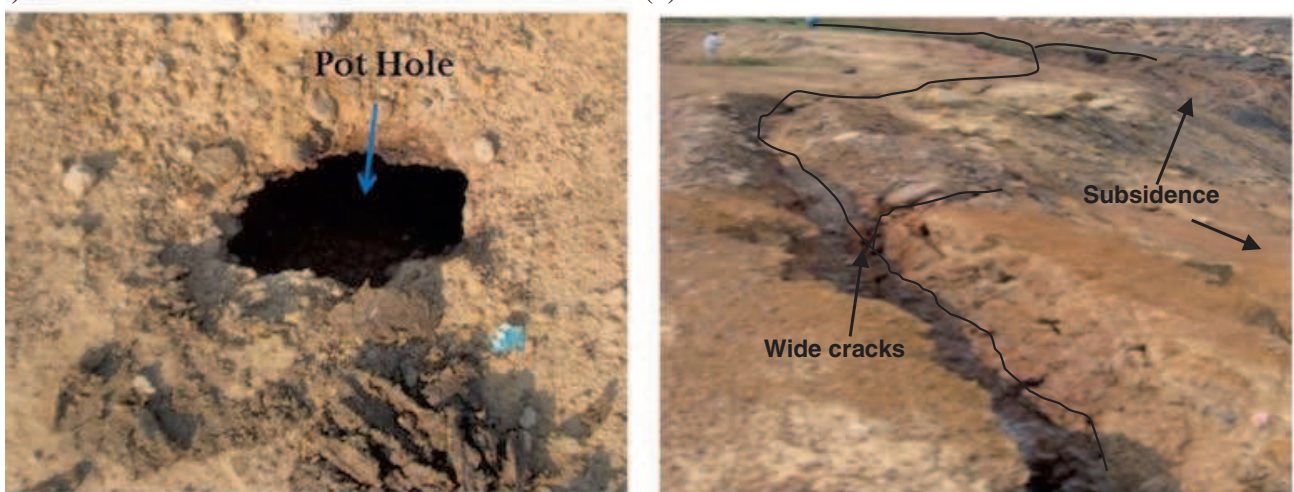

(d)

(e)

Figure 3. (a) Magnetic anomaly map after pole reduction of residual magnetic field intensity map of East Basuria Colliery. L1-L12, results due to subsurface coal fire/blaze affected regions and high anomaly (red colour) denoted by H1 to H9, are due to coalfire/blaze free regions, (b) active fire near L1, (c) active fire near L2, (d) active fire through pothole near L3, and (e) widespread cracks and subsidence due to coal fire near L4 and L5. Photographs of burnt/baked rocks near H1, H3, $\mathrm{H} 5$ and $\mathrm{H} 6$ are shown in $(\mathbf{f}),(\mathbf{g}),(\mathbf{h})$, and (i), respectively. Photographs of temperature measurements near L2 $\left(340^{\circ} \mathrm{C}\right)$ and L5 $\left(195.4^{\circ} \mathrm{C}\right)$ are shown in $(\mathbf{j})$ and $(\mathbf{k})$, respectively. 


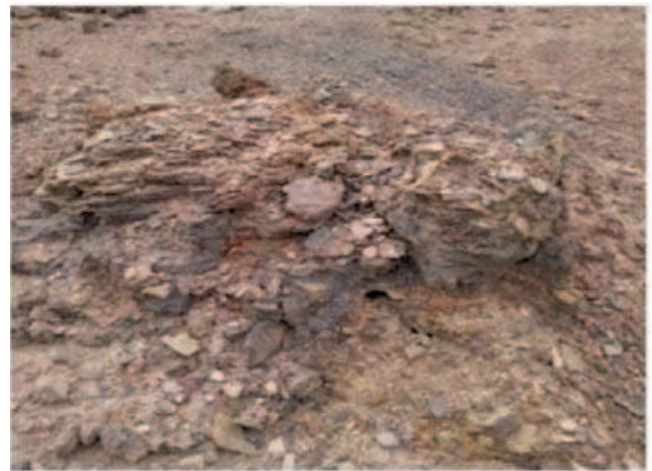

(f)

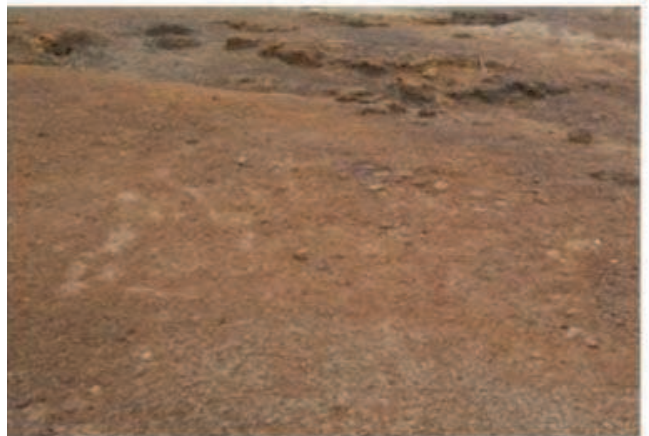

(h)

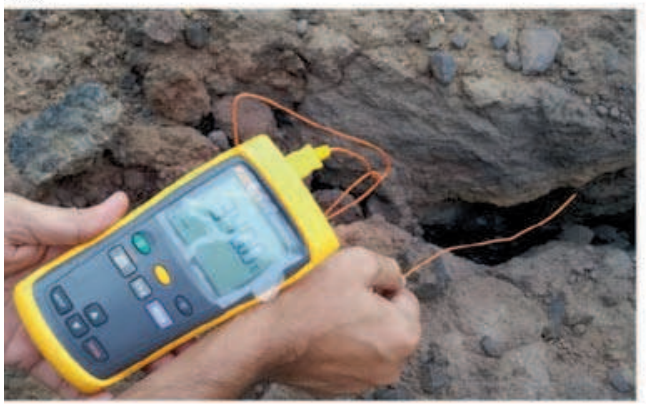

(j)

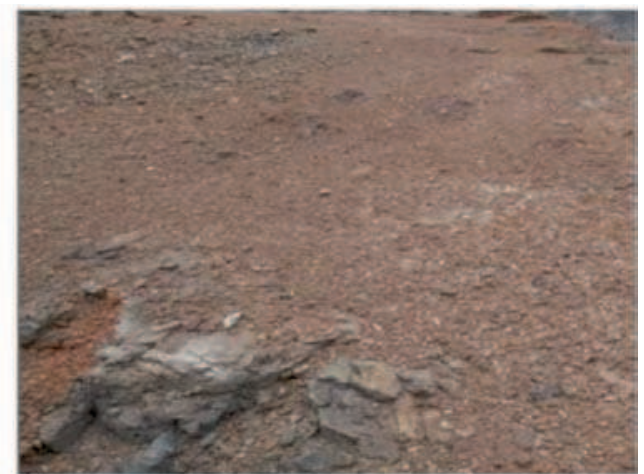

(g)

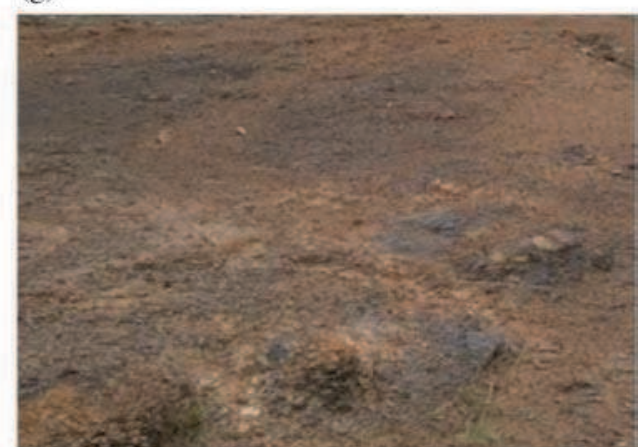

(i)

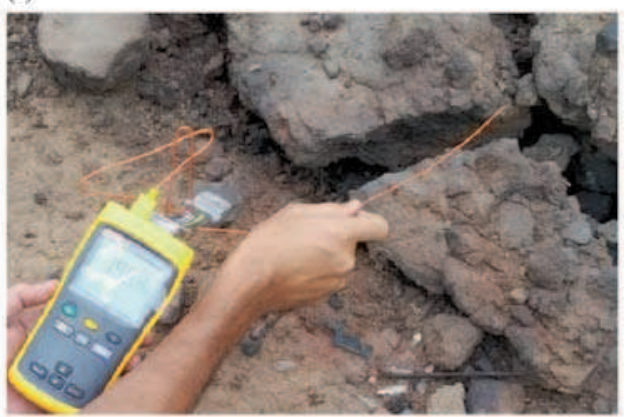

(k)

Figure 3. (Continued.)

through some cracks and fissures (figure 3b). L2 is dominated by subsurface coal fires (figure 3c) with surface temperature of $340^{\circ} \mathrm{C}$ (figure $3 \mathrm{j}$ ). Some small potholes are observed near L3 (figure 3d) caused by subsurface coal fire with surface temperature of $335^{\circ} \mathrm{C}$. Widespread cracks and subsidence due to coal fire are observed near L4 and L5 (figure 3e) with surface temperature of $284^{\circ}$ and $195.4^{\circ} \mathrm{C}$ (figure $3 \mathrm{k}$ ), respectively. Generally, temperatures over cooled and baked rocks near high magnetic anomaly regions vary from $30^{\circ}$ to $34^{\circ} \mathrm{C}$. Photographs of burnt/baked rocks near H1, H3, $\mathrm{H} 5$ and $\mathrm{H} 6$ are shown in figure $3(\mathrm{f}-\mathrm{i})$, respectively. Overburden materials were dumped over H1, H6 and L1, L4, L5, L8 to prevent coal fire activity. However, cracks, fissures, potholes and subsidence are generated due to coal fire resulting in low magnetic anomaly. Details of low magnetic anomaly and high magnetic anomaly and their surface characteristics are given in tables 1 and 2, respectively.
The first vertical derivative (FV) and second vertical derivative (SV) have been calculated from magnetic RTP data (figure 3) of the study area which are shown in figures 4 and 5, respectively. Details of FV anomaly and SV anomaly and their surface characteristics are given in tables 1 and 2, respectively. The different low and high magnetic anomaly zones have been delineated well in the first vertical derivative anomaly map (figure 4) as in the RTP map (figure 3). Further, these anomalies have also been delineated prominently in second vertical derivative anomaly map (figure 5 ). In figure 4, 11 distinct high anomaly regions (FVH1FVH11) have been identified, characterized by first vertical derivative high anomaly (figure 4) which could be related to non-coalfire/blaze free zones. About 19 distinct low anomaly regions (FVL1FVL19) have been identified characterized by first vertical derivative low anomaly, which are mostly affected by coal fire activity as observed on the 
Table 1. Details of low magnetic anomaly and vertical derivative low anomalies with their surface characteristics.

\begin{tabular}{|c|c|c|c|c|c|c|}
\hline Sl. no. & $\begin{array}{l}\text { Magnetic } \\
\text { anomaly }\end{array}$ & $\begin{array}{c}\text { First vertical } \\
\text { derivative } \\
\text { anomaly }\end{array}$ & $\begin{array}{l}\text { Second vertical } \\
\text { derivative } \\
\text { anomaly }\end{array}$ & Central longitude & Central latitude & Surface characteristics \\
\hline 1 & L1 & FVL1 & SVL1 & $86^{\circ} 21^{\prime} 56.25^{\prime \prime} \mathrm{E}$ & $23^{\circ} 47^{\prime} 45.98^{\prime \prime} \mathrm{N}$ & $\begin{array}{l}\text { Active fire/blaze/smoke } \\
\text { through wide fractures/ } \\
\text { fissure }\end{array}$ \\
\hline 2 & $\mathrm{~L} 2$ & FVL2 & SVL2 & $86^{\circ} 21^{\prime} 58.53^{\prime \prime} \mathrm{E}$ & $23^{\circ} 47^{\prime} 44.41^{\prime \prime} \mathrm{N}$ & $\begin{array}{l}\text { Active fire/blaze/smoke } \\
\text { through fissures/cracks }\end{array}$ \\
\hline 3 & L3 & FVL3 & SVL3 & $86^{\circ} 22^{\prime} 0.11^{\prime \prime} \mathrm{E}$ & $23^{\circ} 47^{\prime} 43.38^{\prime \prime} \mathrm{N}$ & $\begin{array}{l}\text { Active fire through pothole } \\
\text { and cracks and subsidence }\end{array}$ \\
\hline 4 & L4 & FVL4 & SVL4 & $86^{\circ} 21^{\prime} 50.58^{\prime \prime} \mathrm{E}$ & $23^{\circ} 47^{\prime} 45.61^{\prime \prime} \mathrm{N}$ & $\begin{array}{l}\text { Widespread cracks and } \\
\text { subsidence due to ire/blaze }\end{array}$ \\
\hline 5 & L5 & FVL5 & SVL5 & $86^{\circ} 21^{\prime} 50.28^{\prime \prime} \mathrm{E}$ & $23^{\circ} 47^{\prime} 50.952^{\prime \prime} \mathrm{N}$ & $\begin{array}{l}\text { Cracks and subsidence due } \\
\text { to fire/blaze }\end{array}$ \\
\hline 6 & L6 & FVL6 & SVL6 & $86^{\circ} 21^{\prime} 47.47^{\prime \prime} \mathrm{E}$ & $23^{\circ} 47^{\prime} 50.34^{\prime \prime} \mathrm{N}$ & $\begin{array}{l}\text { Smoke through pothole/ } \\
\text { fissure }\end{array}$ \\
\hline 7 & L7 & FVL7 & SVL7 & $86^{\circ} 21^{\prime} 44.69^{\prime \prime} \mathrm{E}$ & $23^{\circ} 47^{\prime} 47.637^{\prime \prime} \mathrm{N}$ & Cracks and subsidence \\
\hline 8 & L8 & FVL8 & SVL8 & $86^{\circ} 21^{\prime} 42.98^{\prime \prime} \mathrm{E}$ & $23^{\circ} 47^{\prime} 55.047^{\prime \prime} \mathrm{N}$ & $\begin{array}{l}\text { Pothole and cracks and } \\
\text { subsidence }\end{array}$ \\
\hline 9 & - & FVL9 & SVL9 & $86^{\circ} 21^{\prime} 49.10^{\prime \prime} \mathrm{E}$ & $23^{\circ} 47^{\prime} 49.35^{\prime \prime} \mathrm{N}$ & Cracks and subsidence \\
\hline 10 & - & FVL10 & SVL10 & $86^{\circ} 21^{\prime} 48.55^{\prime \prime} \mathrm{E}$ & $23^{\circ} 47^{\prime} 47.77^{\prime \prime} \mathrm{N}$ & Cracks and subsidence \\
\hline 11 & - & FVL11 & SVL11 & $86^{\circ} 21^{\prime} 48.46^{\prime \prime} \mathrm{E}$ & $23^{\circ} 47^{\prime} 46.7^{\prime \prime} \mathrm{N}$ & $\begin{array}{l}\text { Smoke through fractures/ } \\
\text { fissure }\end{array}$ \\
\hline 12 & - & FVL12 & SVL12 & $86^{\circ} 21^{\prime} 47.73^{\prime \prime} \mathrm{E}$ & $23^{\circ} 47^{\prime} 43.05^{\prime \prime} \mathrm{N}$ & Natural topography \\
\hline 13 & L9 & FVL13 & SVL13 & $86^{\circ} 21^{\prime} 58.31^{\prime \prime} \mathrm{E}$ & $23^{\circ} 47^{\prime} 40.53^{\prime \prime} \mathrm{N}$ & \multirow{4}{*}{$\begin{array}{l}\text { Shallow fire/smoke through } \\
\text { fractures/fissure }\end{array}$} \\
\hline 14 & L10 & FVL14 & SVL14 & $86^{\circ} 21^{\prime} 58.40^{\prime \prime} \mathrm{E}$ & $23^{\circ} 47^{\prime} 41.9^{\prime \prime} \mathrm{N}$ & \\
\hline 15 & L11 & FVL15 & SVL15 & $86^{\circ} 21^{\prime} 56.94^{\prime \prime} \mathrm{E}$ & $23^{\circ} 47^{\prime} 42.8^{\prime \prime} \mathrm{N}$ & \\
\hline 16 & L12 & FVL16 & SVL16 & $86^{\circ} 21^{\prime} 55.61^{\prime \prime} \mathrm{E}$ & $\left.23^{\circ} 47^{\prime} 43.69^{\prime \prime} \mathrm{N}\right)$ & \\
\hline 17 & - & FVL17 & SVL17 & $86^{\circ} 22^{\prime} 0.066^{\prime \prime} \mathrm{E}$ & $23^{\circ} 47^{\prime} 38.09^{\prime \prime} \mathrm{N}$ & Natural topography \\
\hline 18 & - & FVL18 & SVL18 & $86^{\circ} 21^{\prime} 59.43^{\prime \prime} \mathrm{E}$ & $23^{\circ} 47^{\prime} 49.14^{\prime \prime} \mathrm{N}$ & $\begin{array}{l}\text { Shallow fire/smoke through } \\
\text { fractures/fissure }\end{array}$ \\
\hline 19 & - & FVL19 & SVL19 & $86^{\circ} 21^{\prime} 44.61^{\prime \prime} \mathrm{E}$ & $23^{\circ} 47^{\prime} 53.02^{\prime \prime} \mathrm{N}$ & $\begin{array}{l}\text { Shallow fire/pothole and } \\
\text { cracks }\end{array}$ \\
\hline 20 & - & - & SVL20 & $86^{\circ} 21^{\prime} 47.77^{\prime \prime} \mathrm{E}$ & $23^{\circ} 47^{\prime} 51.92^{\prime \prime} \mathrm{N}$ & $\begin{array}{l}\text { Shallow fire/pothole and } \\
\text { cracks }\end{array}$ \\
\hline
\end{tabular}

ground (figure 3b, c, d and e). Further, in figure 5, totally 11 distinct high anomaly regions (SVH1SVH11) have been identified characterized by second vertical derivative high anomaly, which could possibly be related to non-coalfire/blaze free zones. Whereas, about 20 distinct low anomaly regions (SVL1-SVL20) have been identified characterized by second vertical derivative low anomaly, which are mostly affected by coal fire activity, as observed on the ground (figure $3 \mathrm{~b}, \mathrm{c}, \mathrm{d}$ and e).

The corresponding position with approximate shape of the anomalies associated with coal fire and non-coal fire regions have been delineated well in the second vertical derivative anomaly map than the first vertical derivative and RTP anomaly maps. These are correlated well with the surface characteristics (figures 3, 4, 5 and tables 1 and 2). The anomalous bodies occurring near the ground surface produce much stronger gradient effects than those which lie at great depths (Gupta and Ramani 1982; Gupta and Grant 1985; Gupta and Sutcliffe 1990). It is observed that vertical derivatives of residual magnetic anomaly enhance shallow bodies associated with low/high magnetic anomaly caused by coal-fire/fire-free regions and remove the effect of regional ambient magnetic anomaly. In general, the red colour indicates the regions with enhanced magnetic anomaly and the blue colour indicates the regions with reduced magnetic anomaly with respect to the ambient magnetic field over the study area. It is inferred that the red regions indicate the locations which were heated and subsequently cooled, whereas the blue regions indicate the locations which are under active fire and the light green regions are unaffected by the coal fire.

Magnetic susceptibilities have been measured for understanding of anomalous magnetic behaviour 
Table 2. Details of high magnetic anomaly and vertical derivative high anomalies with their surface characteristics.

\begin{tabular}{|c|c|c|c|c|c|c|}
\hline Sl. no. & $\begin{array}{c}\text { Magnetic } \\
\text { anomaly }\end{array}$ & $\begin{array}{l}\text { First vertical } \\
\text { derivative } \\
\text { anomaly }\end{array}$ & $\begin{array}{l}\text { Second vertical } \\
\text { derivative } \\
\text { anomaly }\end{array}$ & Central longitude & Central latitude & Surface characteristics \\
\hline 1 & $\mathrm{H} 1$ & FVH1 & SVH1 & $86^{\circ} 22^{\prime} 0.589^{\prime \prime} \mathrm{E}$ & $23^{\circ} 47^{\prime} 48.16^{\prime \prime} \mathrm{N}$ & $\begin{array}{l}\text { VIII and V/VI seam quarry } \\
\text { partially filled with OB, } \\
\text { previously burned partially } \\
\text { at low } \mathrm{O}_{2} \text { and cooled, } \\
\text { baked rock }\end{array}$ \\
\hline 2 & $\mathrm{H} 2$ & FVH2 & SVH2 & $86^{\circ} 22^{\prime} 0.79^{\prime \prime} \mathrm{E}$ & $23^{\circ} 47^{\prime} 44.36^{\prime \prime} \mathrm{N}$ & $\begin{array}{l}\text { V/VI seam quarry filled } \\
\text { with OB, previously } \\
\text { burned and cooled, } \\
\text { baked rock }\end{array}$ \\
\hline 3 & H3 & FVH3 & SVH3 & $86^{\circ} 22^{\prime} 0.38^{\prime \prime} \mathrm{E}$ & $23^{\circ} 47^{\prime} 40.53^{\prime \prime} \mathrm{N}$ & $\begin{array}{l}\text { Cracks and subsidence, } \\
\text { previously burned partially } \\
\text { at low } \mathrm{O}_{2} \text { and cooled, } \\
\text { baked rock }\end{array}$ \\
\hline 4 & $\mathrm{H} 4$ & FVH4 & SVH4 & $86^{\circ} 21^{\prime} 57.27^{\prime \prime} \mathrm{E}$ & $23^{\circ} 47^{\prime} 44.52^{\prime \prime} \mathrm{N}$ & $\begin{array}{l}\text { Cracks and subsidence, } \\
\text { previously burned partially } \\
\text { at low } \mathrm{O}_{2} \text { and cooled, } \\
\text { baked rock }\end{array}$ \\
\hline 5 & H5 & FVH5 & SVH5 & $86^{\circ} 21^{\prime} 47.18^{\prime \prime} \mathrm{E}$ & $23^{\circ} 47^{\prime} 46.96^{\prime \prime} \mathrm{N}$ & $\begin{array}{l}\text { Cracks, burned out crop/ } \\
\text { indurated sediments, } \\
\text { burned at low } \mathrm{O}_{2} \text { and } \\
\text { cooled }\end{array}$ \\
\hline 6 & H6 & FVH6 & SVH6 & $86^{\circ} 21^{\prime} 49.92^{\prime \prime} \mathrm{E}$ & $23^{\circ} 47^{\prime} 49.36^{\prime \prime} \mathrm{N}$ & $\begin{array}{l}\text { Cracks, baked rock/burned } \\
\text { out crop, burned at low } \mathrm{O}_{2} \\
\text { and cooled }\end{array}$ \\
\hline 7 & $\mathrm{H} 7$ & FVH7 & SVH7 & $86^{\circ} 21^{\prime} 45.40^{\prime \prime} \mathrm{E}$ & $23^{\circ} 47^{\prime} 54.06^{\prime \prime} \mathrm{N}$ & $\begin{array}{l}\text { V/VI seam quarry filled with } \\
\mathrm{OB} \text {, burned at low } \mathrm{O}_{2} \\
\text { and cooled }\end{array}$ \\
\hline 8 & $\mathrm{H} 8$ & FVH8 & SVH8 & $86^{\circ} 21^{\prime} 54.51^{\prime \prime} \mathrm{E}$ & $23^{\circ} 47^{\prime} 41.55^{\prime \prime} \mathrm{N}$ & Normal topography \\
\hline 9 & H9 & FVH9 & SVH9 & $86^{\circ} 21^{\prime} 58.14^{\prime \prime} \mathrm{E}$ & $23^{\circ} 47^{\prime} 38.54^{\prime \prime} \mathrm{N}$ & Normal topography \\
\hline 10 & - & FVH10 & SVH10 & $86^{\circ} 21^{\prime} 53.45^{\prime \prime} \mathrm{E}$ & $23^{\circ} 47^{\prime} 43.88^{\prime \prime} \mathrm{N}$ & $\begin{array}{l}\text { Cracks and subsidence, } \\
\text { burned at low } \mathrm{O}_{2} \text { and } \\
\text { cooled }\end{array}$ \\
\hline 11 & - & FVH11 & SVH11 & $86^{\circ} 21^{\prime} 50.95^{\prime \prime} \mathrm{E}$ & $23^{\circ} 47^{\prime} 43.92^{\prime \prime} \mathrm{N}$ & Normal topography \\
\hline
\end{tabular}

over different parts of the study area. Generally, the samples collected over active fire region indicate susceptibility of about $140 \times 10^{-5}$ to $160 \times 10^{-5}$ SI. However, some samples of fire-affected regions indicate diamagnetic susceptibility of about $-50 \times$ $10^{-5}$ to $-90 \times 10^{-5}$ SI. The magnetic susceptibility for the samples (baked) of old fire-affected area are about $420 \times 10^{-5}$ to $590 \times 10^{-5}$ SI. Whereas, magnetic susceptibility of fresh rock of fire-free regions are about $12 \times 10^{-5}$ to $18 \times 10^{-5}$ SI.

Generally, total magnetic field intensity of an environment is the summation of all the magnetic anomalies associated with ferromagnetic, antiferromagnetic, paramagnetic and diamagnetic objects. Subsurface coal combustion is a chaotic process involving many ill-defined variables. The low magnetic anomaly may have resulted due to a large amount of diamagnetic gases, viz., Carbon dioxide $\left(\mathrm{CO}_{2}\right)$, Methane $\left(\mathrm{CH}_{4}\right)$, Nitrogen $\left(\mathrm{N}_{2}\right)$, Ammonia
$\left(\mathrm{NH}_{3}\right)$, Sulphur dioxide $\left(\mathrm{SO}_{2}\right)$; Hydrogen $\left(\mathrm{H}_{2}\right)$, Carbon monoxide (CO), Selenium (Se), Arsenic (As), Mercury ( $\mathrm{Hg})$, various unsaturated hydrocarbons, water vapour, tar vapours, organic sulphur, hydrogen chlorides and inorganic chlorides, etc., which are generated in underground active coal fire (Schloemer 2006; Engle et al. 2013; Gürdal et al. 2015 , etc.). Further, the pyrolysis of all carbons are characterized by low values of the magnetic susceptibility with both paramagnetic and diamagnetic components. Heat-treatment to graphitizing temperature causes a decrease in the paramagnetic component and a high increase in the diamagnetic part (Jenkins and Kawamura 1976).

Positive magnetic susceptibility of a rock can result from two sources, viz., (i) the presence of iron, nickel, or cobalt-bearing minerals in the rocks and (ii) the degree of alignment of the magnetic moments within these minerals (Hooper 1987). 


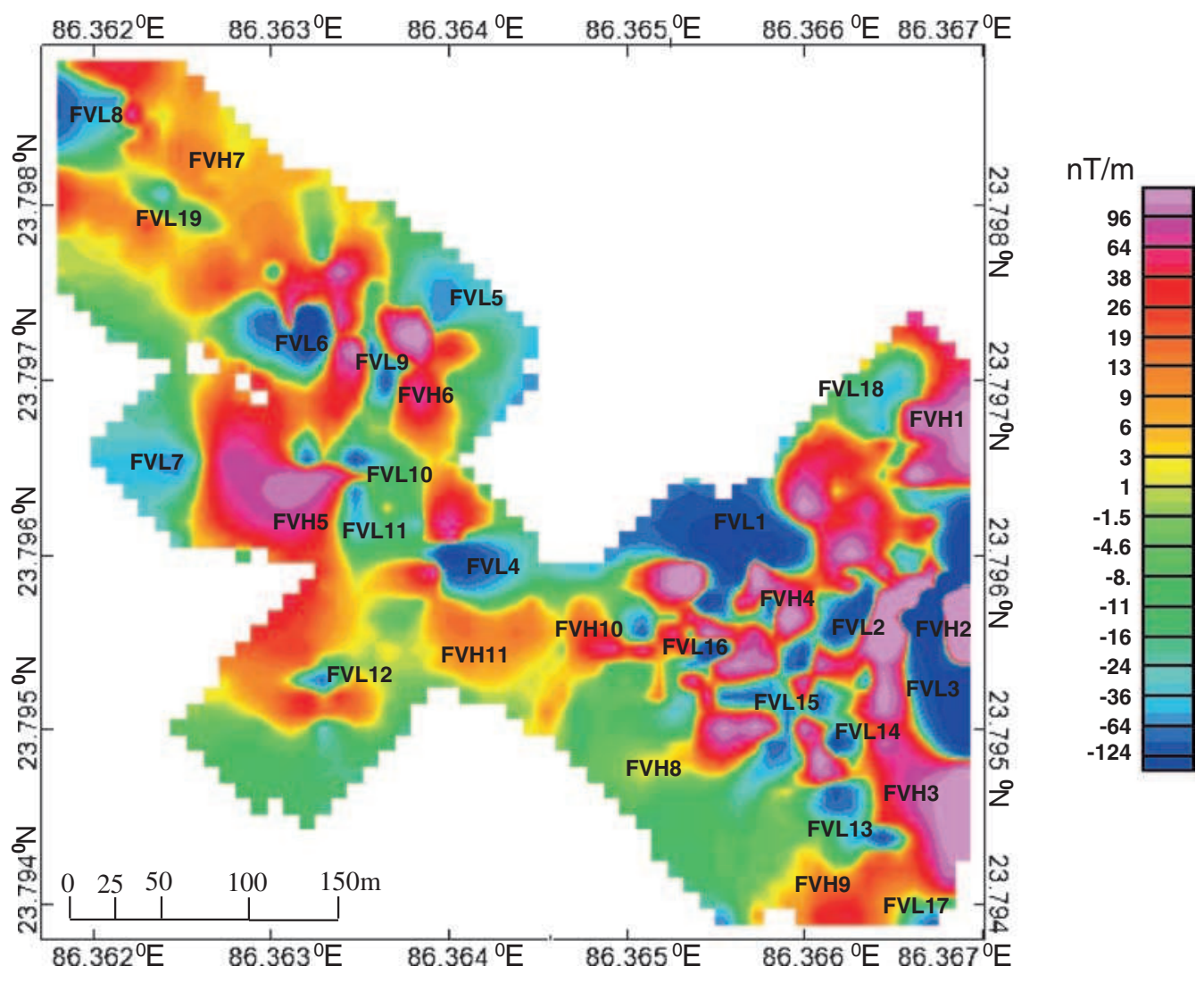

Figure 4. First vertical derivative anomaly (FV) map generated from RTP of residual magnetic field data of East Basuria Colliery. Magnetic anomaly distribution indicating low anomaly (blue colour) denoted by FVL1-FVL19, and high anomaly (red colour) denoted by FVH1 -FVH11, which are in general due to subsurface coal fire/blaze affected regions and noncoalfire/blaze free regions, respectively.

Positive magnetic anomaly may also be associated with fire due to increase in magnetic susceptibility and TRM of overlying rocks (Shao et al. 2014). The overburden/overlying sedimentary rocks (sandstone, shale, etc.) contain traces of magnetic minerals. When the overburden is heated approximately to the Curie temperature, the natural magnetic alignment of magnetic moments and thus the magnetization existing over the area become randomized. Thus, heating above the Curie temperature results in a loss of natural magnetism with a local reduction of the total magnetic field in the vicinity of coalmine fire. Once the coal fire migrates from an area and the overburden cools, the magnetic moments in the overburden become aligned to the Earth's ambient magnetic field which enhances the magnetization of the region. The enhancement is attributed with new preferential alignment of magnetic moments and formation of magnetite in the overburden (Gielisch 2007; Ide et al. 2011). Enhancement of the susceptibilities in the thermally altered rock is likely due to the formation of ferrimagnetic magnetite $\left(\mathrm{Fe}_{3} \mathrm{O}_{4}\right)$ in the shales that have been affected by the heat from the coal fire (Ide and Orr 2011). The process of magnetite and hematite formation is a strong function of $\mathrm{O}_{2}$ availability at temperatures typically observed at coal fires $\left(200^{\circ}-\right.$ $1000^{\circ} \mathrm{C}$ ). Within these temperature ranges, low $\mathrm{O}_{2}$ concentration in deeper multi-seam fire or surface area covered with overburden material/soil, etc., leads to magnetite formation, while high $\mathrm{O}_{2}$ concentration in shallow seam fire with high $\mathrm{O}_{2}$ circulation through widespread fissures, cracks, potholes, etc., leads to hematite formation (Hooper 1987). Rocks such as siltstones and shales over active coal fire regions provide ideal environments for magnetite formation. The low permeability and the low porosity of these rocks limit the diffusion of $\mathrm{O}_{2}$ into the matrix. Hematite $\left(\mathrm{Fe}_{2} \mathrm{O}_{3}\right)$ formation could result owing to heating of shales and siltstones due to subsurface coal fire. This is an antiferromagnetic and thus does not enhance the magnetization of a region upon formation (Ide et al. (Ide et al. 2011).

Regardless of the advantages of magnetometer survey over other coal fire characterization methods, magnetometer measurement could be ineffective in some coal fire sites. The objects such as any magnetic materials, water tanks, train lines, power lines, etc., spread on the nearby surface, may significantly distort the magnetometer measurements with spikes and dropped signals. Coal fires characterization of abandoned mines may not be suitable 


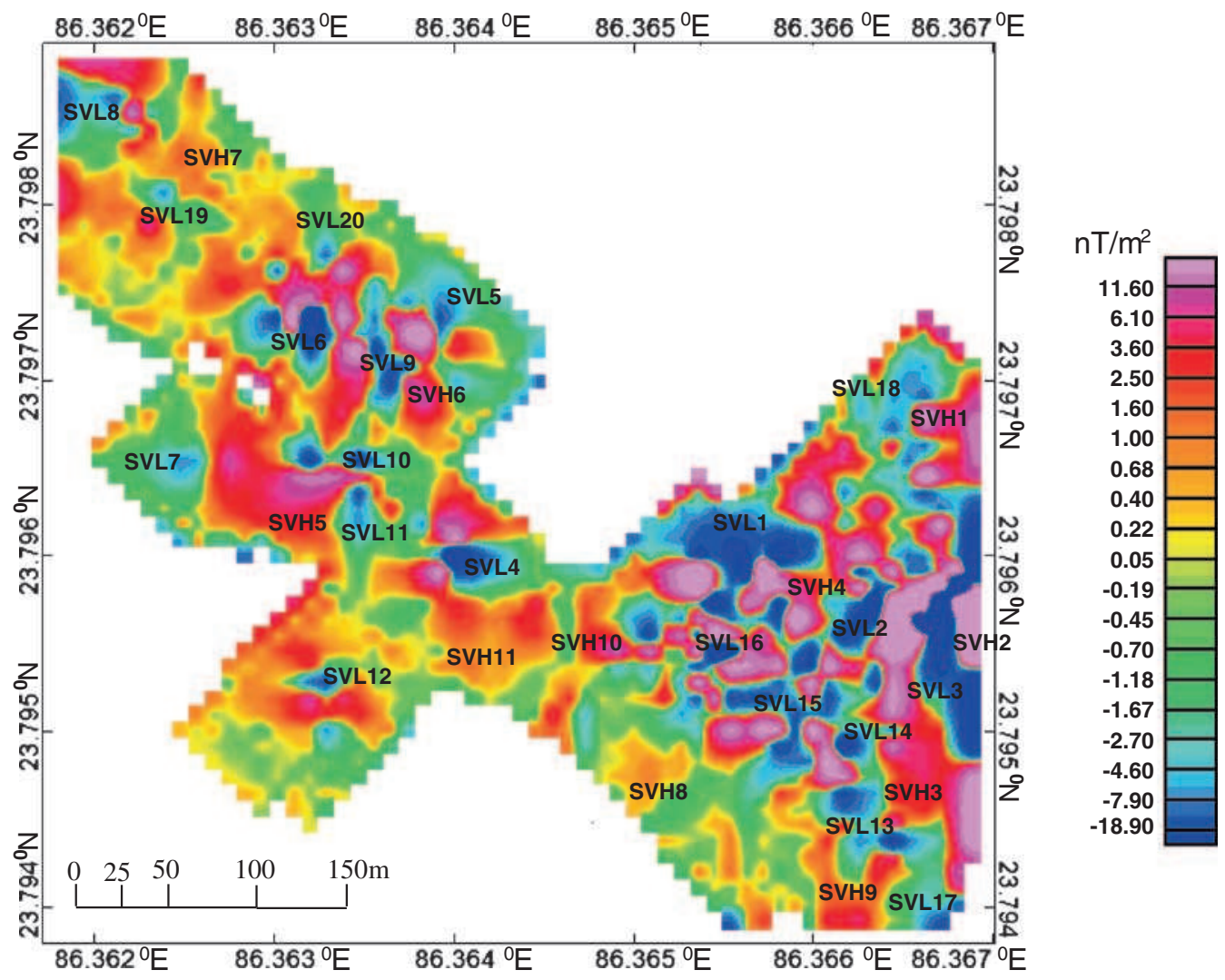

Figure 5. Second vertical derivative anomaly (SV) map generated from RTP of residual magnetic field data of East Basuria Colliery. Magnetic anomaly distribution indicating low anomaly (blue colour) denoted by SVL1-SVL20 and high anomaly (red colour) denoted by SVH1-SVH11, which are generally resulting from subsurface coal fire/blaze affected regions and non-coal fire/blaze free regions, respectively.

by magnetometer measurements if there are metallic objects left which were used during active mining activity. Buried metallic objects can generate several hundred times larger magnetic field than that generated by coal fires. It could overshadow small changes in the anomaly which are associated with coal fires (Ide et al. 2011). In the present study, spikes and dropped signals have been removed and only the readings with good quality signal have been used for analysis.

\section{Conclusions}

It is observed that the total magnetic field intensity anomaly of the area varies from 44850 to $47460 \mathrm{nT}$ and the residual magnetic anomaly varies approximately from -1323 to $1253 \mathrm{nT}$. Whereas, the RTP magnetic anomaly varies approximately from -1050 to $1450 \mathrm{nT}$. Pole reduction removed lateral shifts and asymmetries caused by the local orientation of the magnetic field. Nine magnetic high anomaly $(\mathrm{H} 1-\mathrm{H} 9)$ zones with approximate value of 20-1450 nT and 12 low magnetic anomaly (L1-L12) zones with approximate value of -150 to $-1050 \mathrm{nT}$ have been identified in RTP anomaly map (figure 3a). The first vertical derivative (FV) anomaly (figure 4) of RTP provides sharper resolution for delineation of coal fire affected and non-coal fire region $\$$ han the simple RTP (figure 3 ). Whereas, the second vertical derivative (SV) anomaly (figure 5) of RTP delineates approximate shape and outlines of coal fire affected and non-coal fire regions better than that of the first vertical derivative anomaly (figure 4). The first vertical derivative anomaly map delineates 11 high anomaly regions (FVH1-FVH11) and 19 low anomaly regions (FVL1-FVL19). Whereas, second vertical derivative anomaly map delineates 11 high anomaly regions (SVH1-SVH11) and 20 low anomaly regions (SVL1-SVL20). The high anomalies are mostly associated with cooled and baked rocks, while low magnetic anomalies are mostly caused by coal fire activity.

Magnetism increases slowly with temperature rise until the Curie temperature. Generally, if the temperature of rock/overburden rises above Curie temperature, it loses magnetization and becomes paramagnetic, which results with significant reduction in magnetic susceptibility. However, magnetism greatly increases after cooling below the Curie temperature. The large amount of diamagnetic gases, such as Carbon dioxide $\left(\mathrm{CO}_{2}\right)$, Methane $\left(\mathrm{CH}_{4}\right)$, 
Nitrogen $\left(\mathrm{N}_{2}\right)$, Ammonia $\left(\mathrm{NH}_{3}\right)$, Sulphur dioxide $\left(\mathrm{SO}_{2}\right)$, Hydrogen $\left(\mathrm{H}_{2}\right)$, Carbon monoxide $(\mathrm{CO})$, Selenium (Se), Lead (Pb), Arsenic (As), Fluorine $(\mathrm{F})$, Mercury $(\mathrm{Hg})$, various polycyclic aromatic/ unsaturated hydrocarbons, water vapour, tar vapours, organic sulphur, hydrogen chlorides and inorganic chlorides, etc., are generated in underground active coal seam fire. These are the possible sources of low magnetic anomaly. The other possible source of low magnetic anomaly is pyrolysis process which generates paramagnetic and diamagnetic objects with low magnetic susceptibility. Heat-treatment to graphitizing temperature causes a decrease in the paramagnetic component and a high increase in the diamagnetic part.

The results prove the effectiveness of vertical derivative approach applied on magnetic data for coal fire mapping of East Basuria Colliery, Jharia coalfield, India. The time-lapsed magnetic study using vertical derivative approach would be useful for understanding fire propagation and hazard estimation.

\section{Acknowledgements}

Authors are thankful to DST, Govt. of India for funding a project (SB/S4/ES-640/2012) on geotechnical characterization of Jharia coalfield area using geophysical techniques. Thanks are also due to Associate Editor and anonymous referees, as well as the Editors of the Journal for their suggestions for improving the manuscript. The authors wish to thank the Director, ISM and HOD, Department of Applied Geophysics, ISM, Dhanbad for their keen interest in this study. The authors are grateful to Dr K K K Singh, Senior Principal Scientist, CIMFR; Mr D N Tiwari, East Basuria Colliery for their support at various stages of this study.

\section{References}

Agarwal B N P and Lal T 1969 Calculation of the second vertical derivative of gravity field; Pure Appl. Geophys. 76(1) 5-16.

Agarwal R, Singh D, Chauhan D S and Singh K P 2006 Detection of coalmine fires in the Jharia coalfield using NOAA/AVHRR data; J. Geophys. Eng. 3 212-218.

Blakely R 1996 Potential theory in gravity and magnetic applications; Cambridge University Press, Cambridge, UK, 435p.

Bandelow F K and Gielisch H F 2004 Modern exploration methods as key to fighting of uncontrolled coal fires in China; Denver Annual Meeting, Denver, CO.

Baranov V 1957 A new method for interpretation of aeromagnetic maps, pseudo gravimetric anomalies; Geophysics 22 359-363.

Baranov V and Naudy H 1964 Numerical calculation of the formula of reduction to the magnetic pole; Geophysics $\mathbf{2 9}$ 67-79.
Bell F G, Bullock S E T, Halbich T F J and Lindsay P 2001 Environmental impacts associated with an abandoned mine in the Witbank Coalfire, South Africa; Int. J. Coal Geol. 45 195-216.

Bharti A K, Pal S K and Vaish J 2014 Application of Selfpotential method for coal fire detection over Jharia Coal field; 51st Annual convention of Indian Geophysical Union, Kurukshetra University, Kurukshetra, 19-21 November, 59-62.

Bharti A K, Pal S K, Priam P, Kumar S, Shalivahan and Yadav P K 2016 Subsurface cavity detection over Patherdih colliery, Jharia Coalfield, India using electrical resistivity tomography; Env. Earth Sci. (in press).

Bharat Coking Coal 2003 Brief history of BCCL Dhanbad, Bharat Coking Coal Ltd.; http://bccl.nic.in/About-us. htm.

Bhattacharya A, Reddy S and Mukherjee T 1991 Multi-tier remote sensing data analysis for coal fire mapping in Jharia coalfield of Bihar, India; Asian Conference on Remote Sensing, Singapore, 30 October-5 November, 1, 22-1-6.

Boschetti F 2005 Improved edge detection and noise removal in gravity maps via the use of gravity gradients; J. Appl. Geophys. 57 213-225.

Breiner S 1999 Application manual for portable magnetometers; Geometrics Inc., San Jose, CA.

Burgmann R, Rosen P and Fielding E 2000 Synthetic aperture radar interferometry to measure Earth's surface topography and its deformation; Ann. Rev. Earth Planet. Sci. 28 169-209.

Chatterjee R S 2006 Coal fire mapping from satellite thermal IR data - a case example in Jharia coalfield, Jharkand, India; ISPRS J. Photogramm. Rem. Sens. 60 113-128.

Chen M and Shao W 2010 The application of the ground magnetic method in the exploration of fire area boundary of the coalfield; Geophys. Geochem. Explor. 34(1) 89-92.

CMPDI 2003 Scheme for dealing with fire for protection of KT Link Line at East Busseriya Colliery; pp. 1-16.

Coal International 2003 Coal India plans 53 mine closures; Industry News 251(3) 107.

Engle M A, Olea R A, O'Keefe J M K, Hower J C and Geboy N J 2013 Direct estimation of diffuse gaseous emissions from coal fires: Current methods and future directions; Int. J. Coal Geol. 112 164-172.

Fedi M and Florio G 2001 Detection of potential fields source boundaries by enhanced horizontal derivative method; Geophys. Prospect. 49 40-58.

Fedi M and Florio G 2002 A stable downward continuation by using ISVD method; Geophys. J. Int. 151 146-156.

Fedi M and Florio G 2013 Determination of the maximumdepth to potential field sources by a maximum structural index method; J. Appl. Geophys. 88 154-160.

Gangopadhyay P K 2003 Coal fire detection and monitoring in Wuda, North China: A multispectral and multi-sensor approach; MSc dissertation, International Institute for Geo-Information Science and Earth Observation (ITC), Enschede, The Netherlands.

Gangopadhyay P K 2006 Application of remote sensing to identify coalfires in the Raniganj coalbelt, India; Int. J. Appl. Earth Observ. Geoinform. 8 188-195.

Gielisch H 2007 Detecting concealed coal fires; Rev. Eng. Geol. 18 199-210.

Gonenc T 2014 Investigation of distribution of embedded shallow structures using the first order vertical derivative of gravity data; J. Appl. Geophys. 104 44-57.

Grant F S and Dodds J 1972 MAGMAP FFT Processing System Development Notes; Paterson Grant and Watson Limited, 230p. 
Gupta V K and Ramani N 1982 Optimum second vertical derivatives in geological mapping and mineral exploration; Geophysics 47 1706-1715.

Gupta V K and Grant F S 1985 Mineral-exploration aspects of gravity and aeromagnetic surveys in the SudburyCobalt area, Ontario: In the utility of regional gravity and aeromagnetic anomaly maps; Soc. Explor. Geophysicists, Spec. Vol., pp. 392-411.

Gupta V K and Sutcliffe R H 1990 Mafic-ultramafic intrusives and their gravity field: Lac des lles area, northern Ontario; Geol. Soc. Am. Bull. 102 1417-1483.

Gürdal G, Hoşgörmez H, Özcan D, Li X, Liu H and Song W 2015 The properties of Çan Basin coals (Çanakkale Turkey): Spontaneous combustion and combustion byproducts; Int. J. Coal Geol. 138 1-15.

Hood P J, Holroyd M T and McGrath P H 1979 Magnetic method applied to base metal exploration; In: Geophysics and geochemistry in the search for metallic ores (ed.) Hood P J, Ministry of Supply and Services Canada, Ottawa, Ontario, pp. 77-104.

Hooper R L 1987 Factors affecting the magnetic susceptibility of baked rocks above a burned coal seam; Int. J. Coal Geol. 9 157-169.

Ide T S, Crook N and Orr F M 2011 Magnetometer measurements to characterize a subsurface coal fire; Int. J. Coal Geol. 87 190-196.

Ide T S and Orr F M 2011 Comparison of methods to estimate the rate of $\mathrm{CO}_{2}$ emissions and coal consumption from a coal fire near Durango, CO; Int. J. Coal Geol. 86 95-107.

Jenkins G M and Kawamura K 1976 Polymeric carbons carbon fibre, glass and char; Cambridge University Press, $183 p$.

Khalil M H 2012 Magnetic, geo-electric, and groundwater and soil quality analysis over a landfill from a lead smelter, Cairo, Egypt; J. Appl. Geophys. 86 146-159.

Kuenzer C, Zhang J, Li J, Voigt S, Mehl H and Wagner W 2007a Detection of unknown coal fires: Synergy of coal fire risk area delineation and improved thermal anomaly extraction; Int. J. Rem. Sens. 28 4561-4585.

Kuenzer C, Zhang J, Tetzlaff A, Voigt S, Van Dijk P, Wagner W and Mehl H 2007b Uncontrolled coal fires and their environmental impacts: Investigating two arid mining environments in north-central China; Appl. Geograph. $2742-62$.

Kuenzer C, Zhang J, Hirner A, Bo Y, Jia Y and Sun Y 2008 Multitemporal in situ mapping of the Wuda coal fires from 2000 to 2005 assessing coal fire dynamics; In: Spontaneous coal seam fires: Mitigating a global disaster: ERSEC ecological book series, UNESCO Beijing, 4 132148.

Kuenzer C and Stracher G B 2011 Geomorphology of coal seam fires; Geomorphology 138(1) 209-222.

Kumar S, Pal S K, Vaish J and Shalivahan 2015 Utilization of Magnetic Gradient Method for Coal Fire Mapping of Chatabad Area, a Part of Jharia Colafield, India; J. Eng. Geol. Spec. Pub. pp. 170-176.

Mansor S B, Cracknell A P, Shilin B V and Gornyi V I 1994 Monitoring of underground coal fires using thermal infrared data; Int. J. Rem. Sens. 15 1675-1685.

Marcotte D L, Hardwick C D and Nelson J B 1992 Automated interpretation of horizontal magnetic gradient profile data; Geophysics 57 288-295.

Massonnet D and Feigle K L 1998 Radar interferometry and its application to changes in the Earth's surface; Rev. Geophys. 36 441-500.

Mendonca C A and Silva B C 1993 A stable truncated series approximation of the reduction-to-the-pole operator; Geophysics 58 1084-1090.
Michalski S R 2004 The Jharia mine fire control technical assistance project: An analysis; Int. J. Coal Geol. 59 $83-90$.

Mishra R, Bahuguna P and Singh V 2011 Detection of coal mine fire in Jharia coalfield using Landsat-7 ETM+ data; Int. J. Coal Geol. 86 73-78.

Pal S K and Majumdar T J 2015 Geological appraisal over the Singhbhum-Orissa Craton, India using GOCE, EIGEN6-C2 and in-situ gravity data; Int. J. Appl. Earth Obs. Geoinf. 35 96-119.

Prakash A, Saraf A K, Gupta R P and Sundaram R M 1995 Surface thermal anomalies associated with underground fires in Jharia coal mines, India; Int. J. Rem. Sens. 16 2105-2109.

Prakash A, Gupta R P and Saraf A K 1997 A Landsat TM based comparative study of surface and subsurface fire in the Jharia Coalfield, India; Int. J. Rem. Sens. 18(11) 2463-2469.

Prakash A and Gupta R P 1998 Land-use mapping and change detection in a coal mining area - a case study in the JCF, India; Int. J. Rem. Sens. 19 391-410.

Prakash A and Gupta R P 1999 Surface fires in JCF, Indiatheir distribution and estimation of area and temperature from TM data; Int. J. Rem. Sens. 20 1935-1946.

Rao D A, Babu H V and Narayan P V 1981 Interpretation of magnetic anomalies due to dikes: The complex gradient method; Geophysics 46 1572-1578.

Ravat D 1996 Analysis of the Euler method and its applicability in environmental magnetic investigations; J. Environ. Eng. Geophys. 1(3) 229-238.

Reid A B, Allsop J M, Granser H, Millett A J and Somerton I W 1990 Magnetic interpretation in three dimensions using Euler deconvolution; Geophysics 55 80-91.

Rosema A, Guan H, Genderen J L V, Veld H, Vekerdy Z, Katen A M T, Prakash A and Sharif M 1999 Manual of coal fire detection and monitoring; Report of the project: Development and implementation of a coal fire monitoring and fighting system in China, 245p.

Saraf A K, Prakash A, Sengupta S and Gupta R P 1995 Landsat-TM data for estimating ground temperature and depth of subsurface coalfire in the Jharia coalfield, India; Int. J. Rem. Sens. 16 2111-2124.

Schaumann G, Siemon B and Yu C C 2008 Geophysical investigation of Wuda coal mining area, Inner Mongolia: Electromagnetics and magnetics for coal fire detection; In: Spontaneous coal seam fires: Mitigating a global disaster (ed.) Mera, International Research for Sustainable Control and Management, ERSEC Ecological Book Series, UNESCO, 4. Tsinghua University Press and Springer, Beijing, pp. 336-350.

Schloemer S 2006 Innovative technologies for exploration, extinction and monitoring of coal fires in north China; Final report on gas and temperature measurements at fire zones, Federal Institute for Geosciences and Natural Resources (BGR), D-30655 Hannover, Germany, pp. $1-53$.

Schueck P E J 1990 Using a magnetometer for investigating underground coal mine fires, burning coal refuse banks, and for locating AMD source areas on surface mines; Mining and Reclamation Conference and Exhibition, Charleston, West Virginia, April 23-26.

Shao Z, Wang D, Wang Y and Zhong X 2014 Theory and application of magnetic and self-potential methods in the detection of the Heshituoluogai coal fire, China; J. Appl. Geophys. 104 64-74.

Singh A K, Singh R V, Singh M P, Chandra H and Shukla N P 2007 Mine fire gas indices and their application to Indian underground coal mine fires; Int. J. Coal Geol. 69 192-204. 
Singh B B, Srivardhan V, Pal S K, Kanagaraju S K, Kumar S and Vaish J 2015 Particle swarm optimization inversion of self potential anomaly for detecting coal fires: A case study - Jharia coal field; Third Sustainable Earth and Sciences conference in Celle, Germany, EAGE, 13 October, doi: 10.3997/2214-4609.201414282.

Singh K K K, Singh K B, Lokhande R D and Prakash A 2004 Multi-electrode resistivity imaging technique for the study of coal seam; J. Scient. Indus. Res. 63 927-930.

Srivardhan V, Pal S K, Vaish J, Kumar S, Bharti A K and Priyam P 2016 Particle swarm optimization inversion of self-potential data for depth estimation of coal fires over East Basuria colliery, Jharia coalfield, India; Env. Earth Sci. (in press).

Song Z and Kuenzer C 2014 Coal fires in China over the last decade: A comprehensive review; Int. J. Coal Geol. 133 72-99.

Stracher G B 2004 Coal fires burning around the world: A global catastrophe; Int. J. Coal Geol. 59 1-6.

Stracher G B and Taylor T P 2004 Coal fires burning out of control around the world: Thermodynamic recipe for environmental catastrophe; Int. J. Coal Geol. 59 7-17.

Sternberg R and Lippincott C 2004 Magnetic surveys over clinkers and coal seam fires in western North Dakota; Presentation at the Denver Annual Meeting of the Geological Society of America, Denver, Colorado, U.S.A., 7-10 October.

Sternberg R, Sparks A and Knutson O 2008 Magnetic surveys over burning and remediated coal seam fires in western North Dakota; Proceedings of the Symposium on the Application of Geophysics to Engineering and Environmental Problems: SAGEEP, 21, doi: 10.2113/ 1.2963279 .

Tripathi D D 2005 Prevention and control of coal fires in sealed-off areas of coal mines using different means of inertization; Proceedings of the International Conference on Coal Fire Research, Beijing, China, 29 November-1 December, pp. 179-181.

Vaish J and Pal S K 2013 Interpretation of magnetic anomaly data over east Basuria region using an enhanced local wavenumber (ELW) technique; 10th
Biennial International Conference and Expositionon Petroleum Geophysics, Kochi, 23-25 November, 110 p.

Vaish J and Pal S K 2015a Subsurface coal fire mapping of East Basuria Colliery, Jharkhand; J. Geol. Soc. India 86(4) 438-444.

Vaish J and Pal S K 2015b Geological mapping of Jharia coalfield, India using GRACE EGM 2008 gravity data: A vertical derivative approach; Geocarto Int. 30(4) 388-401.

Vaish J and Pal S K 2016 Subsurface coal fire mapping of Patherdih Colliery a part of Jharia coal field, India; J. Geol. Soc. India (in press).

Voigt S, Tetzlaff A, Zhang J, Kuenzer C, Zhukov B, Strunz G, Oertel D, Roth van Dijk P and Mehl H 2004 Integrating satellite remote sensing techniques for detection and analysis of uncontrolled coal seam fires in North China; Int. J. Coal Geol. 59 121-136.

Wachiwicz J 2008 Analysis of underground fires in Polish hard coal mines; J. China Univ. Mining and Tech. 18(3) 332-336.

Wei M, Guo W B and Dai W Z 2005 The application of high precision magnetic measurement in determining the border of coalfield fire; Northwest Coal 3(1) 26-28.

World Bank Group 2003 Jharia Mine Fire Control Technical Assistance Project; Project ID INP010411, Borrower: Bharat Coking Coal Limited. http://www4.worldbank. org/sprojects/Project.asp?pid=P010411.

Xiong S and Yu C 2013 Characteristics and mechanisms of rock magnetic increasing in underground coal spontaneous combustion area-take Wuda coal mine of Inner Mongolia and Ruiqigou coal mine in Ningxia as examples; Chinese J. Geophys. 56 2828-2836.

Zhang X S 1980 The detection of coal seam fire with magnetic method; Coal Geol. Explor. 6 43-48.

Zhang X M 1998 Coal fires in Northwest China: Detection, monitoring, and prediction using remote sensing data; Ph.D. dissertation, International Institute for GeoInformation Science and Earth Observation (ITC).

Zhang J, Wagner W, Prakash A, Mehl H and Voigt 2004 Detecting coal fires using remote sensing techniques; Int. J. Rem. Sens. 25 3193-3220. 